\section{Understanding of science}

SIR-Durant, Evans and Thomas (Nature $340,11-14 ; 1989$ ) rightly point out that public understanding of science is essential in a highly technological democracy. But they do not address the question of whether our representatives understand science any better than the general public. When will they apply their test to Members of Parliament (MPs)? If we can be guided by the experience of the United States, where a test a few years ago showed that 60 per cent of US senators could not name five African countries (including such obscure ones as South Africa), the results may be rather depressing: what hope for sensible legislation on CFC emissions or spare-part surgery if nearly 200 MPs believe the Sun goes round the Earth?

\section{PA Consulting Group, \\ Cambridge Laboratory, \\ Melbourn}

Royston,

Herts SG8 6DP, UK

SIR-At first sight, it was surprising and depressing to read that 30 per cent of 2,000 members of the British public questioned thought that the Sun went round the Earth. But then I remembered the words of Dr Thomas Arnold, who was headmaster of Rugby School in the 1830 s and who is often described as the founder of the modern British public school. $\mathrm{He}$ feared that physical science was such a large subject that it would dominate the school curriculum, to the exclusion of the inculcation of Christian, moral and political philosophy. He knew where his priorities lay. In a letter to a friend, he said: "Rather than have physical science the principal thing in my son's mind [his son was Matthew Arnold, later to be an inspector of schools as well as a poet], I would gladly have him think that the sun went round the earth and the stars were so many spangles set in the bright blue firmament".

\section{Huddersfield Road \\ West Bretton,}

DAVID DAVIES

Wakefield, UK

SIR-Here are two very recent quotations on a similar theme: (1) "Nuclear power stations are a cause of acid rain", sourcenearly half of Britons surveyed by Durant et al., and (2) "Nuclear power is irrelevant to the prevention of global warming", source - 100 of the country's leading scientists doctors and engineers (Greenpeace declaration, most daily papers, 5 July 1989).

These two quotations provide a neat complementarity of misinformation; about $\mathrm{SO}_{2}$ and $\mathrm{NO}_{x}$ emissions by the first group and $\mathrm{CO}_{2}$ emissions by the second group. This is dispiriting to scientists involved with investigating causes and consequences of acid rain and the greenhouse effect. Let us hope that as the science proceeds to dispel some of the scientific uncertainties, the standard of debate will also take an upturn.

\section{Climate Change Research}

MAX BERAN

\section{Terrestrial and Freshwater Sciences}

Directorate,

Natural Environment Research Council, Institute of Hydrology,

Wallingford, Oxon OX10 8BB, UK

\section{Events in China}

SIR-Like many others, I have been saddened and appalled by recent events in China and have wondered what can be done to register a meaningful protest. I think there is one way that scientists can have an impact. Many organizations have planned meetings and conventions in China that would bring significant amounts of hard currency into the country. These meetings should be cancelled and re-scheduled elsewhere. How can we attend meetings in a country where our colleagues are under arrest, where too much fraternizing with foreigners can compromise them, perhaps leading to punishment of them or their families after the meeting is over?

Only by widespread, concerted action will such a protest have an effect; I urge all who are planning to hold or attend meetings in China in the near future to consider their colleagues - some now dead or under arrest - and to decide whether this is an appropriate time to be carrying on business as usual.

RAYMONDS. BRADLEY Department of Geology and Geography, University of Massachusetts,

Morrill Science Center,

Amherst, Massachusetts 01003, USA

\section{Fraud in science}

SIR-I agree with Efraim Racker (Nature 339, 91; 1989) that fraud in science is ugly, but there are always three parties involved: the victim (the scientific community), the offender and his boss. We all know what may happen. The "unbalanced mind" working at the "forefront" is told by his supervisor that he has an idea which, if proved, will be a "breakthrough". What that will mean is clear. This is the beginning. No bad guy, no good guy. Just someone who hears what he wants to hear and someone who supplies. The pressure may come from within but this does not exonerate the supervisor from responsibility.

Fraud in science is not a political but a moral question. But it is first a moral question for the supervisor. Co-workers working for their doctorate are very dependent. So fraud in science is also the deception of beginners by established scientists.

THOMAS FRIEDRICH

6074 Rödermark 2,

Ahornstrasse 9, FRG

\section{Science and slides}

SIR-Scientists use slides as an important way to exchange information at scientific meetings. Modern computerized techniques in general lead to better slides. Nevertheless, on almost every occasion we experience the frustrations of failing slide projection. One common problem is the mismatch between the thickness of the slides and the corresponding part of the slide projector. I advise US colleagues not to bring slides that are too thin when they come to Europe. Conversely, the thinner slides work better for Europeans when we go to the United States. And, of course, we should all leave paper-framed slides at home.

Rijksuniversiteit te Utrecht,

BEN DE KRUIJFF

Instituut voor Moleculaire Biologie

en Medische Biotechnologie,

Postbus 80.063,

3508 TB Utrecht, The Netherlands

\section{Dispute resolved}

SIR-This letter is intended to put an end to a dispute concerning speculative models for the possible role of reverse transcription in:

(1) the production of antigen-directed mutations in the antibody genes of antigenstimulated B lymphocytes (Steele, E.J. \& Pollard, J.W. Molec. Immun. 24, 667$673 ; 1987)$;

(2) the production of substrate-directed mutations in certain bacterial genes (Cairns, J., Overbaugh, J. \& Miller, S. Nature 335, 142-145; 1988).

These speculations had their origin in Temin's ideas about the possible role of retroviruses and reverse transcription in the genesis of biological variation (Temin, H.M. Perspect. Biol. Med. 14, 11-26; 1970 and J. Natn. Cancer Inst. 46, iii-vii; 1971).

One of us (E.J.S.), in a letter he distributed to many people, has claimed that the other (J.C.) was guilty of plagiarism. He now acknowledges that the allegation was unfounded and he withdraws it.

E. J. Steele

Department of Biology,

University of Wollongong, NSW and

Division of Cell Biology,

John Curtin School of Medical Research, Canberra, Australia

Department of Cancer Biology,

Harvard School of Public Health,

Boston, Massachusetts, USA 